\title{
Hepatic Enlargement of Breast-fed Infants and its Relation to Nutritional Dystrophy of their Mothers
}

Studies on the Nutrition of Ghildren in Hirosaki Area (24th Report)

By

\author{
Tsuneo Arakawa, Yuji Sato, and Akira Kagaya \\ (荒川雅 男) (佐藤雄 治) (加賀谷 晃)
}

From the Department of Pediatrics, School of Medicine, Hirosaki

University, Hirosaki. Director: Prof. Ts. Arakawa

(Received for publication, December 27, 1954)

According to Arakawa et al. ${ }^{11}$ the incidence of hepatic enlargement was higher among the children with nutritional dystrophy than among those without it.

In the present paper, hepatic enlargement of the breast-fed infants and its relation to nutritional dystrophy of their mothers and to the riboflavine content in the mother's milk will be reported.

\section{EXPERIMENTAL}

\section{Materials and Method}

The materials subjected to this investigation were restricted to those who were exclusively breast-fed, of the age under 12 months and were free from any complaints of illness.

These infants were selected from those who attended at a Baby show which was held on August 28, 1935 in two rural villages (Miyoshi-village and Rokugo-village, both situated at Tsugaru District in Aomori Prefecture).

These infants were divided into two groups: Group A consisted of those who were fed on the milk from the mothers without nutritional dystrophy and Group B consisted of those who were fed on the milk from the mothers with nutritional dystrophy.

Riboflavine content in mother's milk was estimated by means of lumiflavin-fluorometric method ${ }^{2}$.

The palpation of the liver was made on the right nipple line and measured in centimeters below the costal margin, The "liver palpable $3 \mathrm{~cm}$.", for example, means " the liver was palpable and $3 \mathrm{~cm}$. long below 
the costal margin on the nipple line".

\section{Results and Comment}

Relation between nutritional dystrophy of mothers and hepatic enlargement of the breast-fed infants (Cf. Tables I and II).

\section{TABLE I}

Relation between Enlargement of the Liver of Breast-Fed-Infants and Riboflavine Content in Milk from the Mothers with or without Nutritional Dystrophy

\begin{tabular}{|c|c|c|c|c|c|c|c|c|c|}
\hline$\frac{a}{3}$ & $\begin{array}{l}\text { No. of } \\
\text { case }\end{array}$ & $\begin{array}{c}\text { Age } \\
\text { (m.) } \\
\text { and sex }\end{array}$ & $\begin{array}{l}\text { Liver } \\
\text { (cm.) }\end{array}$ & $\begin{array}{l}\text { Riboflavine } \\
\text { in mother's } \\
\text { milk }(r \%)\end{array}$ & 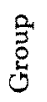 & $\begin{array}{l}\text { No. of } \\
\text { case }\end{array}$ & $\begin{array}{c}\text { Age } \\
\text { (m.) } \\
\text { and sex }\end{array}$ & $\begin{array}{l}\text { Liver } \\
\text { (cm.) }\end{array}$ & $\begin{array}{c}\text { Riboflavine } \\
\text { in mother's } \\
\text { milk }(r \%)\end{array}$ \\
\hline \multirow{27}{*}{ 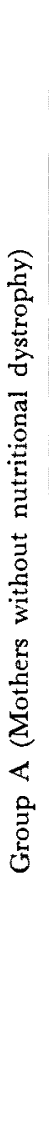 } & 1 & 2. $\delta$ & 3 & 34.3 & \multirow{27}{*}{ 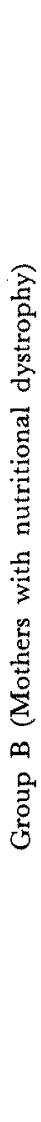 } & 27 & 6. 9 & 1.8 & 28.3 \\
\hline & 2 & 2. $\hat{\delta}$ & 2 & 35.5 & & 28 & 2. 우 & 2.5 & 39.9 \\
\hline & 3 & 2. 우 & 1.5 & 37.2 & & 29 & 2. 우 & 1.8 & 37.2 \\
\hline & 4 & 2. $\delta$ & - & 46.3 & & 30 & 2. 우 & 3.5 & 19.2 \\
\hline & 5 & 2. 우 & 1.5 & 26.9 & & 31 & 5. 우 & 3.5 & 25.6 \\
\hline & 6 & 3. 우 & - & 22.3 & & 32 & 4. 우 & 1.8 & 20.8 \\
\hline & 7 & 3. $\delta$ & 0.5 & 26.8 & & 33 & 4. $\delta$ & 1.0 & 18.9 \\
\hline & 8 & 4. $\hat{8}$ & 2.0 & 32.4 & & 34 & 7. $\delta$ & 1.8 & 30.0 \\
\hline & 9 & 4. 우 & - & 49.4 & & 35 & 6. $\mathbf{8}$ & 3.5 & 23.3 \\
\hline & 10 & 4. 우 & - & 20.3 & & 36 & 7. 우 & 1.0 & 15.3 \\
\hline & 11 & 4. 우 & 一 & 22.3 & & 37 & 4. $\delta$ & 1.8 & 30.2 \\
\hline & 12 & 4. 우 & $\ldots$ & 22.3 & & 38 & 5. $\delta$ & - & 19.4 \\
\hline & 13 & 4. 우 & 4.0 & 48.0 & & 39 & 6. 8 & 1.0 & 16.5 \\
\hline & 14 & 4. 우 & 1.0 & 33.4 & & 40 & 1. 우 & 1.8 & 30.9 \\
\hline & 15 & 5. 우 & - & 36.7 & & 41 & 3. & 1.8 & 25.9 \\
\hline & 16 & 5. 우 & - & 26.6 & & 42 & 4. $\widehat{0}$ & 1.0 & 14.8 \\
\hline & 17 & 5. 今 & - & 38.6 & & 43 & 3. 今 & 1.8 & 24.2 \\
\hline & 18 & 5. 종 & 3.5 & 36.0 & & 44 & 4. 우 & 3.5 & 23.2 \\
\hline & 19 & 5. 今 & 2.5 & 33.4 & & 45 & 6. & 3.5 & 31.6 \\
\hline & 20 & 5. 우 & - & 31.5 & & 46 & 6. 우 & 3.5 & 29.2 \\
\hline & 21 & 7. 우 & - & 35.1 & & 47 & 4. 우 & 2.5 & 32.4 \\
\hline & 22 & 7. 우 & - & 35.3 & & 48 & 1. $\delta$ & 2.5 & 16.3 \\
\hline & 23 & 7. 우 & 1.5 & 40.3 & & 49 & 4. $\delta$ & 3.5 & 11.5 \\
\hline & 24 & 11. $\delta$ & 2.0 & 20.6 & & 50 & 7. 9 & 1.0 & 28.5 \\
\hline & 25 & 11. 우 & - & 25.0 & & & & Average & $24.6 \pm 3.3$ \\
\hline & 26 & 12. 우 & 1.5 & 30.0 & & & & & \\
\hline & & & & $32.7 \pm 2.7$ & & & & & \\
\hline
\end{tabular}

Out of the 50 cases examined, 14 cases were those without palpable liver, and of which 13 cases $(92.8 \%$ ) belonged to Group A and only one 


\section{TABLE II}

Relation between Nutritional Dystrophy of Mothers and Enlargement of the Liver of the Breast-fed Infants

\begin{tabular}{c|c|c|c|c|c}
\hline \multirow{2}{*}{ Group } & $\begin{array}{c}\text { Nutritional } \\
\text { dystrophy of } \\
\text { the mothers }\end{array}$ & \multicolumn{3}{|c|}{$\begin{array}{c}\text { The liver of the breast-fed infants (cm. below the } \\
\text { costal margin on the right nipple line) }\end{array}$} \\
\cline { 3 - 6 } & $\begin{array}{c}\text { Not palpable } \\
\text { (cases) }\end{array}$ & $\begin{array}{c}\text { Less than } 3 \mathrm{~cm} . \\
\text { (cases) }\end{array}$ & $\begin{array}{c}3 \mathrm{~cm} \text {. or more } \\
\text { (cases) }\end{array}$ & Total \\
\hline A & $(-)$ & 13 & 10 & $\begin{array}{l}3 \\
(11.5 \%)\end{array}$ & 26 \\
B & $(+)$ & $\begin{array}{l}7 \\
(50.0 \%)\end{array}$ & 16 & $\begin{array}{l}7 \\
(29.1 \%)\end{array}$ & 24 \\
\hline & Total (cases) & 14 & 26 & 10 & 50
\end{tabular}

cases to Group B. On the other hand, the cases with the liver palpable $3 \mathrm{~cm}$. or more were 10 cases out of the 50 cases examined, and of which 7 cases $(70.0 \%$ ) belonged to Group B and only 3 cases to Group A.

In the normal infants of the age under 12 months, the liver was palpable 1 to 2 fingers breadth ${ }^{3)}$ or 2 to $3 \mathrm{~cm}^{4 / 5)}$ below the costal margin on the right nipple line.

Concerning Japanese healthy infants, Matumoto and Tsukine') reported that the liver was not palpable in $303(41.1 \%)$ out of 734 cases of the infants of the age under 6 months and in $569(53.5 \%)$ out of 1064 cases of the infants of the age from 7 to 12 months, and they also reported that the liver palpable $3 \mathrm{~cm}$. or more was found in $166(9.2 \%)$ out of 1798 cases of the infants of the age under 12 months.

In the present investigation, the liver was not palpable in $13(50.5 \%)$ out of the 26 cases of Group A, and in only one case (4.1\%) out of the 24 cases of Group B. On the other hand, the liver which was palpable $3 \mathrm{~cm}$. or more was found in 7 cases $29.1 \%$ ) of Group B and 3 cases $(11.5 \%$ ) of Group A.

It may therefore be concluded that the incidence of the cases in which the liver was palpable $3 \mathrm{~cm}$. or more was higher in Group B than in Group $\mathrm{A}$ and that the incidence of the cases without palpable liver was lower in Group B than in Group A.

Relation between the hepatic enlargement of the breast-fed infants and riboflavine content of their mother's milk (Cf. Table III).

According to Kagaya ${ }^{71}$, one of us, there was a close relation between ariboflavinotic sigins (such as angular stomatitis, cheilosis and atrophy or/and swelling of the lingual papillae) and the blood riboflavine level of the children with nutritional dystrophy.

As will be seen from Table $\mathrm{I}$, the averages of ribofiavine content in 
TA B L E III

Relation between Riboflavine Content of Mother's Milk and Enlargement of the Liver of Breast-fed Infants

\begin{tabular}{c|c|c|c|c}
\hline $\begin{array}{c}\text { Riboflavine } \\
\text { content } \\
\text { in mother's } \\
\text { milk }(\mathrm{T} \%)\end{array}$ & $\begin{array}{c}\text { The liver of the breast-fed infants (cm. below the } \\
\text { costal margin on the right nipple line) }\end{array}$ \\
\cline { 2 - 4 } $\begin{array}{c}\text { Below } \\
25.0\end{array}$ & 5 & $\begin{array}{c}\text { Less than } 3 \mathrm{~cm} . \\
\text { (cases) }\end{array}$ & $\begin{array}{c}3 \mathrm{~cm} \text {. or more } \\
\text { (cases) }\end{array}$ & Total \\
\hline $21.5 \sim 35.0$ & 2 & 4 & 17 & 19 \\
\hline $\begin{array}{c}\text { Above } \\
35.1\end{array}$ & 7 & 13 & 4 & 14 \\
\hline Total (cases) & 14 & 5 & 10 & 50 \\
\hline
\end{tabular}

mother's milk were $32.7 \pm 2.7 \gamma \%$ and $24.6 \pm 3.3 \gamma \%$ in Group $A$ and Group B respectively, that is to say, riboflavine content was significantly lower in the milk from the mothers with nutritional dystrophy than in that from those without nutritional dystrophy. But, as will be seen from Table III, any significant relations were not found between the riboflavine content in mother's milk and the incidence of the cases with or without liver enlargement.

According to Sebrell et al. ${ }^{\mathbf{8 9 1 0 1}}$ gross fatty liver was said to develop in riboflavine deficiency.

We are of the opinion that ariboflavinotic signs, which were found commonly among children in Hirosaki area, are not to be taken merely as symptoms of ariboflavinosis, but outgh to be considered as one of manifestations of nutritional dystrophy'1112).

Arakawa et al. ${ }^{1 \prime}$ found that the incidence of the cases in which the liver was palpable $4 \mathrm{~cm}$. or more was higher in children with nutritional dystrophy than in those without it. Sato and Arakawa ${ }^{13)}$ reported 3 cases of hepatomegalic liver in chronic miliary tuberculosis of children and described that a main cause of hepatic enlargement must be sought in the nutritional dystrophy prevalent among children in this area.

The components of mother's milk were decidedly altered by thiamine deficiency of the lactating mothers ${ }^{14}$.

Agostini ${ }^{15)}$ reported, after milk analysis of many pellagrous mothers, that the milk showed a composition not different from that of the normal in fats and sugars, but that it showed a deficiency in casein and excess in salts.

Lucaletto $^{15)}$ called atention to the deficiency of iron in the milk of pellagrins. 
Simonini ${ }^{15}$ ) found that, in addition to an increase in salt and a decrease in casein, there was also a deficiency in iron, and he also suspected the presence of unidentified toxic principles in the milk of pellagrins.

From the present investigation, it may therefore be concluded that the high incidence of hepatic enlargement of the infants who were fed on the milk from the mothers with nutritional dystrophy, is not to be ascribed merely to the low riboflavine content in the milk, but to possible alteration in other factor or factors in the milk of the mothers with nutritional dystrophy.

\section{Summary and Conclusions}

- The high incidence of hepatic enlargement was found among the infants who were fed on the milk from the mothers with nutritional dystrophy.

The hepatic enlargement of the breast-fed infants seemed to be closely related to nutritional dystrophy of the lactating mothers, but it may be not merely ascribed to the low riboflavine content in the milk of those mothers.

This work was carried out by a Grant in aid for Developmental Scientific Research of the Ministry of Education. Ts. Arakawa.

\section{References}

1) Arakawa, Ts., Sato, Y., Izurumachi, A. \& Morinaga, Ch., Hepatic enlargement of children with nutritional dystrophy. In press in this Journal.

2) Kagaya, A., Vitamins (Japan), 1953, 6, 777.

3) Feer, E., Lehrbuch der Kinderheilkunde., 11th ed., Jena, 1934, 15.

4) Müller, E., Ernährung und Behandlung des Kindes, Stuttgart, 1936, 20.

5) Holt's Diseases of Infancy and Childhood, 11 th ed., New York and London, 1940, 466.

6) Matsumoto, T. \& Tsukine, K., Cited from Hara's Practice in Pediatrics (Japan.). 1st ed., Nanzando, Tokyo, 1953, 777.

7) Kagaya, A., Vitamins (Japan.), 1954, 7, 557.

8) Sebrell, W. H., Pub. Health Rep., 1929, 44, 2697.

9) Sebrell, W. H. \& Onstott, R. H., ibid., 1938, 53, 83.

10) Sebrell, W. H., Onstott, R. H. \& Hunt, D. H., ibid., 1937, 52, 1427.

11) Masuda, K. \& Aoyama, J., Tohoku J. Exp. Med., 1951, 55, 1.

12) Arakawa, Ts., Wada, Sh. \& Takahashi, F., ibid., 1951, 55, 61.

13) Sato, Y. \& Arakawa, Ts., ibid., 1952, 56, 59.

14) Sato, A., Arakawa, Ts. \& Naito, T., ibid., 1947-48, 49, 211.

15) Cited from Gillman and Gillman's Perspectives in Human Malnutrition, 1st ed., Grune \& Stratton, New York, 1951, 477-481. 